\section{Clinical significance of P53 and $\mathrm{BCl}-2$ in acute myeloid leukemia patients of Eastern India}

\author{
Geetaram Sahu, ${ }^{1}$ Rabindra kumar Jena ${ }^{2}$ \\ 1 Molecular Oncology and Medical \\ Biotechnology Division, Institute of Life \\ Sciences, Chandrasekharpur, \\ Bhubaneswar, Orissa; ${ }^{2}$ Dept of Clinical \\ Haematology, S.C.B Medical College \\ Hospital, Cuttack, Orissa, India
}

\begin{abstract}
The frequency of p53 and $\mathrm{Bcl}-2$ protein expression in 100 newly diagnosed and 10 relapsed acute myeloid leukemia (AML) patients was analyzed by immunocytochemistry (ICC). The Kaplan-Meier method was used for univariate and multivariate statistical analysis to assess the relationship between p53, Bcl-2 and clinico-hematologic feature with respect to overall survival (OS) using SPSS statistical software. No statistical significance was found in univariate analysis $(\mathrm{P}=0.60)$. However, when the subgroups of patients $(+1,+2,+3$ and +4$)$ were compared, expression of p53 and Bcl-2 protein (1-10\%, 11$30 \%, 31-50 \%$ and $>50 \%$ ) was statistically significant $(\mathrm{P}<0.05)$. However, in multivariate analysis, p53, immunopositivity was independently associated with a shorter overall survival (OS) $(\mathrm{P}=0.038)$ while $\mathrm{Bcl}-2$ immunopositivity was associated with longer overall survival (OS) $(\mathrm{P}=0.002)$. Our finding shows that $\mathrm{p} 53$ and $\mathrm{Bcl}-2$ protein overexpression is a strong indicator of response to chemotherapy and overall survival. This study reports for the first time AML in patients from Eastern India.
\end{abstract}

\section{Introduction}

Mutation of the p53 gene has been found in a wide variety of neoplastic diseases and functions as a specific transcriptional gene activator $^{1}$ controlling the $\mathrm{Gl}$ check point of the cell cycle, DNA repair, synthesis and apoptosis. ${ }^{2-5}$ Mutations of the p53 gene are the most common genetic alteration in human cancer. ${ }^{2,6}$ The wild-type p53 protein has a short half-life and cannot be detected by immunocytochemistry in cells. Mutated p53 on the other hand, has a prolonged half-life and can be detectable by immunocytochemistry. Mutation of the p53 gene has been reported in only $5-10 \%$ of patients with acute myeloid leukemia but when present is associated with a low complete remission rate, early relapse and poor survival. ${ }^{7-10}$ Accumulation of altered p53 protein has been reported to be an indicator of poor prognosis. ${ }^{2-5}$ The Bcl-2 gene, the first member of a rapidly expanding family of genes that inhibit apoptosis, was initially isolated from the $t(14 ; 18)$ chromosomal translocation found in human B-cell lymphoma. ${ }^{11}$ Relatively high levels of $\mathrm{Bcl}-2$ protein have been expressed in $20 \%$ of patients with AML. ${ }^{12} \mathrm{Bcl}-2$ is the best characterized of the proteins and its role in the pathogenesis and prognosis of AML has been studied with conflicting results. ${ }^{13-16}$ These studies have found that patients with higher levels of Bcl-2 have a lower remission rate, an inferior survival or both ${ }^{13,14}$ and, in contrast, the patients who do not express Bcl-2 had low remission rates and higher relapse rates than those with intermediate levels of Bcl-2. ${ }^{15,16}$

Several studies indicate that the protein expression levels of $\mathrm{Bcl}-2$ determine the in vitro sensitivity of leukemic cells to chemotherapeutic drugs. A high level of Bcl-2 protein confers a survival advantage on B cells by inhibiting apoptosis and may block a common cell death pathway induced by chemotherapy. High levels of Bcl-2 expression confer resistance to apoptosis induced by chemotherapeutic drugs and association of Bcl-2 with poor prognosis in AML patients and other types of cancer. ${ }^{12,17-20} \mathrm{Bcl}-2$ protein expression has been shown to predict poor outcome in acute myeloid leukemia but conflicting results have been reported for ALL. ${ }^{21-23}$ In the present study, we examined specifically the protein expression of p53 and Bcl-2 in de novo acute myeloid leukemia patients before treatment and correlated their clinical and hematologic parameters to overall survival (OS).

\section{Materials and Methods}

\section{Patients}

This study includes 100 de novo and 10 relapsed de novo AML patients diagnosed in the Department of Clinical Hematology, S.C.B. Medical College, Cuttack, India. Diagnosis and classification of AML was made using the French-American-British (FAB) classification after conventional cytochemical stains and surface marker analysis.

\section{Peripheral blood monocyte isola- tion}

Using heparin as an anti-coagulant, $3 \mathrm{ml}$ of blood were collected from AML patients. The heparinized blood was diluted in $3 \mathrm{ml}$ of sterile PBS (pH 7.4). The PBS mixed blood was placed on a Ficoll Hypaque layer (density 1.077 $\mathrm{gm} / \mathrm{m}^{2}$ ) in a $15 \mathrm{~mL}$ centrifuge tube; the proportion between the Ficoll Hypaque layer and blood should be 1:3 and 2:3, respectively. After
Correspondence: Dr. Geetaram Sahu, Department of Physiology, College of Medicine UT Health Science Center, Memphis, USA. TN 38103, USA. Tel. +1.301.538.4858.

E-mail:sahugr@yahoo.com

Key words: p53, Bcl-2, AML, protein expression, survival.

Acknowledgments: the author thanks the department of Clinical Hematology SCB Medical College Hospital, Cuttack for providing leukemic patient samples.

Received for publication: 22 August 2011.

Revision received: 24 September 2011.

Accepted for publication: 24 October 2011.

This work is licensed under a Creative Commons Attribution NonCommercial 3.0 License (CC BYNC 3.0).

(OC) Copright G. Sahu and R. kumar Jena, 2011

Licensee PAGEPress, Italy

Hematology Reports 2010; 3:e28

doi:10.4081/hr.2011.e28

centrifugation for $1,500 \mathrm{rpm}$ for $30 \mathrm{~min}$, the middle layer, which contains lymphocytes and blast cells, was collected without touching the Ficoll Hypaque layer. The lymphocytes were diluted with $1 \mathrm{ml} \mathrm{PBS}$, and then washed twice in $1 \mathrm{ml}$ PBS.

\section{Immunocytochemistry}

Both p53 and Bcl-2 immunostained samples were taken from 5 positive controls and 5 negative controls. Lymphocyte fixations were performed in methanol. These slides were incubated for $10 \mathrm{~min}$ in $1.5 \%$ hydrogen peroxide. After rinsing in distilled water and TBS $(\mathrm{pH}=7.6)$, the slides were incubated with $1 \%$ blocking buffer (BSA) in TBS ( $\mathrm{pH}=7.6)$ for 20 min to suppress the non-specific binding of immunoglobulin. Specific immunostaining was evaluated by means of overnight incubation at $4^{\circ} \mathrm{C}$ with the appropriate primary antibody (PAB 240, Calbiochem, USA) which can recognize both wild- and mutant type p 53 protein in 1:100 dilutions. Mouse monoclonal antibody (Bcl2) was used to detect Bcl-2 proteins. The mouse monoclonal antibody (IgG1) Bcl-2, clone 124, is raised against an epitope between amino acid 41 and 54 of the Bcl-2 protein (1:100; Dako Corporation, Denmark). After washing in TBS, a secondary biotinylated goat anti-mouse/rabbit antibody (Dako Corporation, Denmark) was applied for 30 min. Slides were rinsed with TBS and incubated with streptavidin for $30 \mathrm{~min}$. The peroxidase reaction was performed by incubating for $20 \mathrm{~min}$ in a developing solution containing diaminobenzedine (Sigma, USA). Finally, the slides were rinsed in TBS and then counterstained with hematoxylin. The blast cells and lymphocytes have been differentiated accord- 
ing to their morphological appearance; blast cells are larger in size with a more prominent nucleus than the smaller size lymphocytes. At least 1,000 cells were counted and the results were expressed as the percentage of positive cells. Slides were scored as immunonegative if no leukemic cells stained. Slides were scored as $+1(1-10 \%),+2(11-30 \%),+3(31-50 \%)$ and +4 (>50\% positive cells). ${ }^{25,24}$

\section{Statistical analysis}

Univariate analysis was performed using the Kaplan-Meier method. ${ }^{26}$ The difference in survival between groups was evaluated by the $\log$ rank test. Multivariate analysis was performed using Cox's regression method ${ }^{27}$ with stepwise forward selection of independent variables based on the likelihood ratio. $\mathrm{P}<0.05$ was considered statistically significant.

\section{Results}

Immunostaining for p53 and Bcl-2 was successful in 110 AML patients. Patients' clinical characteristics are listed in Table 1.

\section{Expression of p53 and $\mathrm{Bcl}-2$ is het- erogeneous in all-FAB types}

A broad range of $\mathrm{p} 53$ and Bcl-2 protein expression was seen in FAB types (M1-M5) and in none of the patients with M6 and M7 FAB types, as shown in Table 1. There was a statistical difference in dispersion of p53 and Bcl-2 protein expression. Ten of the 110 patients had died at the time of analysis. Statistical analysis strongly indicated that Bcl2 had a higher threshold effect on survival than $\mathrm{p} 53$.

\section{p53 expression and survival}

Among the 110 patients, 100 (91\%) patients were p53 immunopositive while 10 (9\%) patients were p53 immunonegative. Of the p53 immunopositive cases, 6 (5\%) contained 1$10 \%$ of p53-positive cells, 22 (20\%) had 11$30 \%, 16(14 \%)$ had $31-50 \%$ and $56(51 \%)$ had highly expressed, i.e. more than 50\%, p53 immunopositive leukemic cells. The relationship between p53 and Bcl-2 protein expression for the cut off used for scoring is shown in Table 2. We compared the p53-immunostaining results with the clinical outcome of patients. The number of patients with p53 immunonegative $(n=10)$ had a longer survival rate. However, a comparison of the p53-positive $v s$ negative subgroup (Figure 1A) failed to reach statistical significance $(\mathrm{P}=0.60, \log$ rank test). Kaplan-Meier curves showed that overall survival was shorter in subgroups +3 and +4 than in subgroups +1 and +2 . There was a statistically significant difference in clinical outcome between the patient subgroups $(+3$
A (Kaplan-Meier Survival Curve)

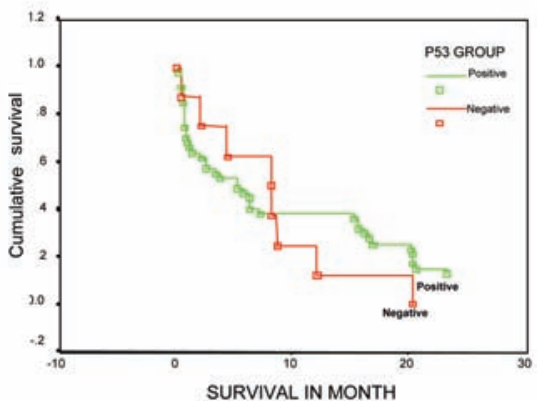

B (Kaplan-Meier Survival Curve)

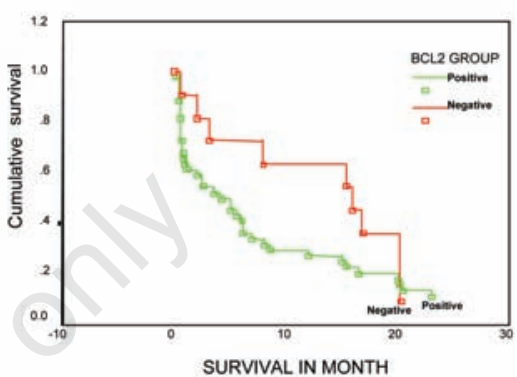

Figure 1. (A) Kaplan-Meier survival curve showing survival functions with $\mathrm{p} 53$ positive versus p53 negative. (B) Kaplan-Meier survival curve showing survival functions with $\mathrm{Bcl}-2$ positive versus $\mathrm{Bcl}-2$ negative.

Table 1. Patients' characteristics according to P53 and BCL-2 immunostaining $(n=110)$.

\begin{tabular}{|c|c|c|c|c|c|c|c|c|c|}
\hline Parameter & N. patients & Category & N. & p53 +ve & p53 -ve & P value & Bcl 2+ve & Bcl 2-ve & $P$ value \\
\hline Sex & 110 & $\begin{array}{c}\text { Female } \\
\text { Male }\end{array}$ & $\begin{array}{l}42(38.18) \\
68(61.81)\end{array}$ & $\begin{array}{c}38(90.4) \\
62(91.17)\end{array}$ & $\begin{array}{c}4(9.5) \\
6(91.17)\end{array}$ & NS & $\begin{array}{l}34(80.95) \\
62(91.17)\end{array}$ & $\begin{array}{c}8(19.04) \\
6(8.82)\end{array}$ & NS \\
\hline Age & 110 & $\begin{array}{c}>2<10 \text { year } \\
>40<60\end{array}$ & $\begin{array}{c}10(9.09) \\
100(90.90)\end{array}$ & $\begin{array}{l}10(100) \\
90(90)\end{array}$ & $\begin{array}{c}\text { NIL } \\
10(10)\end{array}$ & NS & $\begin{array}{l}10(100) \\
86(86)\end{array}$ & $\begin{array}{c}0 \\
14(14)\end{array}$ & NS \\
\hline WBC at diagnosis & 110 & $\begin{array}{l}<50 \times 10^{9} / \mathrm{L} \\
\geq 50 \times 10^{9} / \mathrm{L}\end{array}$ & $\begin{array}{l}72(65.45) \\
38(34.54)\end{array}$ & $\begin{array}{c}62(86.11) \\
38(100)\end{array}$ & $\begin{array}{c}10 \text { (13.88) } \\
\text { NIL }\end{array}$ & NS & $64(88.88)$ & $8(11.11)$ & NS \\
\hline TPC at diagnosis & 110 & $\begin{array}{l}<50 \times 10^{9} / \mathrm{L} \\
\geq 50 \times 10^{9} / \mathrm{L}\end{array}$ & $\begin{array}{l}72(65.45) \\
38(34.54)\end{array}$ & $\begin{array}{l}64(88.88) \\
36(94.73)\end{array}$ & $\begin{array}{l}8(11.11) \\
2(5.26)\end{array}$ & NS & $\begin{array}{l}66(91.66) \\
30(78.94)\end{array}$ & $\begin{array}{c}6(8.33) \\
8(21.05)\end{array}$ & NS \\
\hline Lymphodeno-pathy & 110 & $\begin{array}{l}\text { No } \\
\text { Yes }\end{array}$ & $\begin{array}{l}74(67.27) \\
36(32.72)\end{array}$ & $\begin{array}{l}66(89.18) \\
34(94.44)\end{array}$ & $\begin{array}{c}8(10.81) \\
2(5.55)\end{array}$ & NS & $\begin{array}{l}66(89.18) \\
30(83.33)\end{array}$ & $\begin{array}{l}8(10.81) \\
6(16.66)\end{array}$ & NS \\
\hline Splenomegaly & 110 & $\begin{array}{l}\text { No } \\
\text { Yes }\end{array}$ & $\begin{array}{l}68(61.81) \\
42(38.18)\end{array}$ & $\begin{array}{l}64(94.11) \\
36(85.71)\end{array}$ & $\begin{array}{c}4(5.88) \\
6(14.28)\end{array}$ & NS & $\begin{array}{l}66(97.05) \\
30(71.42)\end{array}$ & $\begin{array}{c}2(2.94) \\
12(28.57)\end{array}$ & NS \\
\hline Hepatomegaly & 110 & $\begin{array}{l}\text { No } \\
\text { Yes }\end{array}$ & $\begin{array}{l}76(69.09) \\
34(30.90)\end{array}$ & $\begin{array}{c}66(86.84) \\
34(100)\end{array}$ & $\begin{array}{c}10(13.15) \\
\text { NIL }\end{array}$ & NS & $\begin{array}{l}72(94.73) \\
24(70.58)\end{array}$ & $\begin{array}{c}4(5.26) \\
10(29.41)\end{array}$ & NS \\
\hline Mediastinal Mass & 110 & $\begin{array}{l}\text { No } \\
\text { Yes }\end{array}$ & $\begin{array}{l}98(89.09) \\
12(10.90)\end{array}$ & $\begin{array}{l}90(91.83) \\
10(83.33)\end{array}$ & $\begin{array}{c}8(8.16) \\
2(16.66)\end{array}$ & NS & $\begin{array}{c}88(89.79) \\
8(66.66)\end{array}$ & $\begin{array}{c}4(33.33) \\
10(10.20)\end{array}$ & NS \\
\hline Serum LDH & 110 & $\begin{array}{c}\text { Normal } \\
\text { alleviated }\end{array}$ & $\begin{array}{l}32(29.09) \\
78(70.90)\end{array}$ & $\begin{array}{c}28(87.5) \\
72(92.30)\end{array}$ & $\begin{array}{l}4(12.5) \\
6(7.69)\end{array}$ & NS & $\begin{array}{l}26(81.25) \\
70(89.74)\end{array}$ & $\begin{array}{l}6(18.75) \\
8(10.25)\end{array}$ & NS \\
\hline FAB subtypes & 110 & $\begin{array}{l}M_{1} \\
M_{2} \\
M_{3} \\
M_{4} \\
M_{5} \\
M_{6} \\
M_{7}\end{array}$ & $\begin{array}{c}32(29.09) \\
32(29.09) \\
24(21.81) \\
18(16.36) \\
4(3.63) \\
0 \\
0\end{array}$ & $\begin{array}{c}32(100) \\
28(87.5) \\
18(75) \\
18(75) \\
4(100) \\
0 \\
0\end{array}$ & $\begin{array}{c}0 \\
4(12.5) \\
6(25) \\
0 \\
0 \\
0 \\
0\end{array}$ & NS & $\begin{array}{c}28(87.5) \\
28(87.5) \\
18(75) \\
18(100) \\
4(100) \\
0 \\
0\end{array}$ & $\begin{array}{c}4(12.5) \\
4(12.5) \\
6(25) \\
0 \\
0 \\
0 \\
0\end{array}$ & NS \\
\hline
\end{tabular}

*P value denotes the significance of difference between p53 immunopositive Vs p53 immunonegative, and Bcl-2 immunopositive Vs Bcl-2 immunonegative. TPC, total platelet count; LDH, lactate dehydrogenase; FABFrench-American-British, NS, not significant. 
$v s+4, \mathrm{P}=0.0415 ;+2$ vs $+4, \mathrm{P}=0.0051 ; 1 v s+3 ;$ $\mathrm{P}=0.0419$; log rank test). However, there was no statistically significant difference between group +1 vs $+2(\mathrm{P}=0.4999$, log rank test,). In multivariate analysis, considering several prognostic parameters such as age, sex, white blood cells (WBC), percentage of blast cells, splenomegaly, hepatomegaly, mediastinal mass and serum LDH, immunopositivity of p53 was associated with shorter overall survival $(\mathrm{P}=0.038)$.

Among 100 p53 immunopositive patients, 9 patients died within 1-20 months (median 11) and 91 were alive at a median follow up of 22 months (range 1-24). On the other hand, among p53 immunonegative patients, one patient died at 15 months and 9 patients were alive at a median follow up of 22 months (range 1-24). The difference between these two groups did not reach statistical significance $(\mathrm{P}=0.60, \log$ rank test).

\section{$\mathrm{Bcl}-2$ protein expression and survival}

Among the 110 patients, 96 (87\%) were Bcl2 immunopositive while 14 (13\%) patients were $\mathrm{Bcl}-2$ immunonegative. Of the Bcl-2 immunopositive cases, 10 (9.09\%) included only a small percentage (1-10\%) of Bcl-2 positive cells, 24 (21.81\%) had low intermediate (11-30\%), 20 (14\%) had high intermediate (31-50\%) and 42 (51\%) had highly expressed (>50\%) Bcl-2 immunopositive leukemic cells.

A comparison of Bcl-2 positive vs negative subgroups did not reach statistical significance $(\mathrm{P}=0.24, \log$ rank test, Figure $1 \mathrm{~B})$. Kaplan-Meier curves showed that overall survival was shorter in subgroups +1 and +4 . The $\log$ rank test showed a statistically significant difference in clinical outcome between subgroups: +1 vs $+2, \mathrm{P}=0.0558 ;+2$ vs +4 , $\mathrm{P}=0.0246 ;+3$ vs $+4 ; \mathrm{P}=0.0021$. However, there was no statistically significant difference between subgroup +1 vs $+3 \quad(\mathrm{P}=0.1729)$ or subgroup +2 vs $+3 \quad(\mathrm{P}=0.3799)$. Multivariate analysis showed that Bcl-2 immunopositivity (>10\%) was associated with a longer overall survival $(\mathrm{P}=0.002)$.

Among 96 Bcl-2 immunopositive patients who were also p53 immunopositive, 5 died within 1-20 months (median 11) and 91 were alive at a median follow up of 22 months (range 1-24). On the other hand, among Bcl-2 negative patients, one patient died at 12 months and 13 patients were alive at a median follow up of 18 months (range 1-24). There was no statistically significant difference between the two groups $(\mathrm{P}=0.24$, log rank test).

\section{Correlation of $\mathrm{Bcl}-2$ with prognos- tic parameter}

We examined the possible association of Bcl-2 protein expression in primary leukemic cells of AML patients and their clinical fea-

Table 2. P53 and BCL-2 immuno-scoring and survival data of AML patients.

\begin{tabular}{lcccccc} 
P53 immunoscore & N. (\%) & $\begin{array}{c}\text { BCL-2 } \\
\text { immunoscore }\end{array}$ & N. (\%) & $\begin{array}{c}\text { FAB } \\
\text { subtypes }\end{array}$ & N. (\%) & $\begin{array}{c}\text { Survival } \\
\text { (range in } \\
\text { months) }\end{array}$ \\
Negative & $10(9.09)$ & Negative & $14(12.72)$ & M1 & $32(29.09)$ & $18-24$ \\
$1-10 \%$ & $6(5.45)$ & $1-10 \%$ & $10(9.09)$ & M2 & $32(29.09)$ & $14-20$ \\
\hline $11-30 \%$ & $22(20)$ & $11-30 \%$ & $24(21.81)$ & M3 & $24(21.81)$ & $15-18$ \\
$31-50 \%$ & $16(14.54)$ & $31-50 \%$ & $20(18.18)$ & M4 & $18(16.36)$ & $9-14$ \\
\hline$>50 \%$ & $56(50.9)$ & $>50 \%$ & $42(38.18)$ & M5 & $4(3.63)$ & $5-9$ \\
Total: & 110 & Total & 110 & Total & 110 & \\
\hline
\end{tabular}

Number of samples with the indicated p53 and Bcl-2 scores of $<1 \%$ (negative), $1-10 \%, 11-30 \%, 31-50 \%$ and $>50 \%$.

tures. Both age and WBC, which were predictive of poor outcome, were associated with a high level of Bcl-2 expression. Leukemic cells from patients with a WBC of $50 \times 10^{9} / \mathrm{L}$ or more showed significantly higher Bcl-2 levels than leukemic cells from patients with a WBC of less than $50 \times 10^{9} / \mathrm{L}$. Age between 40 and 60 years was associated with high $\mathrm{Bcl}-2$ expression. Leukemic cells of patients with splenomegaly or hepatomegaly expressed a high level of Bcl-2.

\section{Discussion}

p53 and Bcl-2 immunostaining data of AML patients were evaluated to establish a possible correlation with overall survival outcome (Tables 1 and 2). For example, patients whose leukemic cells were p53 immunonegative and Bcl-2 immunonegative were associated with a longer overall survival. Steven et al. ${ }^{28}$ reported the correlation between $\mathrm{Bcl}-2$ immunopositive data with clinical outcome and showed longer overall survival in Bcl-2 immunopositive cases. The reason for this is that Bcl-2 and wild-type p53 are commonly expressed in normal B cells. ${ }^{29,30}$ Conflicting data were obtained by different authors regarding p53 and Bcl-2 expression with respect to survival analysis. We observed that p53 immunopositive leukemic cells $(\leq 10 \%)$ were associated with improved survival but Karkas et al. ${ }^{16}$ reported that the patients in their study with p53 immunopositivity had a higher percentage of blast cells, leukocytes and platelets counts, but that these had no influence on the complete remission rate. Similar to other studies, ${ }^{12,13,15,16,30-32}$ expression of Bcl-2 was observed in most of the AML samples and median levels of Bcl-2 expression did not vary. The heterogeneity of expression was similar among FAB types. Acute promyelocytic leukemia cases were observed to have strong expression of Bcl-2 compared to $0,60 \%$, and $75 \%$ reported by Campos et al., ${ }^{12}$ Bankar et al. ${ }^{33}$ and Karakas et al. ${ }^{16}$ respectively. All previous reports agree with this present study in that there is a wide degree of heterogeneity in the expression of
Bcl-2 in AML patients. In our study, high Bcl-2 expression was an adverse prognostic factor for both survival and event-free survival, and was significant as a prognostic factor for remission duration. This finding is similar to those of other workers. ${ }^{12,13,15,16}$ Karkas et al. ${ }^{16}$ have reported that the adverse effect of high Bcl-2 was more prominent in patients aged over 60 . The report by Lauria et al. ${ }^{15}$ did not show the effect of Bcl-2 level on survival, although high Bcl-2 level was associated with a lower complete remission rate.

Campos et al. ${ }^{12}$ reported overexpression of Bcl-2 was correlated with poor treatment outcome in AML patients. Our results showed statistically significant correlations in Bcl-2 immunopositive cases $(\mathrm{P}=0.0038)$ in univariate analysis, while in multivariate analysis prognostic factors such as age at diagnosis, gender, WBC count, platelet count, splenomegaly, hepatomegaly and serum LDH were associated with longer overall survival $(\mathrm{P}=0.002)$. To assess the importance of $\mathrm{Bcl}-2$ expression in pediatric AML, we found a correlation between clinical outcome and level of Bcl-2 protein expression. The correlation of this with patient response to chemotherapy or long-term outcome did not reach statistical significance, which was similar to the findings of other workers. ${ }^{31}$ High levels of Bcl-2 would allow a cell to escape or suppress apoptotic signals, including those induced by chemotherapy. Banker et al. ${ }^{33}$ reported a higher percentage of patients expressing high levels of Bcl-2 at relapse and this difference was not always statistically significant, as reported by Bense $e t$ $a l .{ }^{34}$ We observed that a low level of Bcl-2 was associated with lower response rates, shorter remission duration and inferior survival. A lower level of Bcl-2 was an independent prognostic factor for both survival and remission duration. Karakas et al. ${ }^{16}$ reported that patients with high Bcl-2 level had a better complete remission rate (63 vs 51\%). Lepelley et $a l .{ }^{35}$ reported Bcl-2 levels in MDS patients and observed that high Bcl-2 was a favorable prognostic finding. In the study by Maung et al., ${ }^{13}$ none of the patients with secondary leukemia and lower levels of Bcl-2 expression achieved CR. However, this cannot be compared with 
the present study due to the small sample size and low remission rate. From our study, it is clear that the Bcl-2 protein expression is significantly higher than in normal controls, which is consistent with other reports. ${ }^{36}$ This indicates that the alteration of Bcl-2 is an important mechanism in the pathogenesis, progress and the development of drug resistance in AML. Bcl-2 might have a different role in disease pathogenesis and leukemic progression, thus giving different prognostic implications to the same level of expression. This distinction could have important therapeutic implications for future therapies designed to induce apoptosis or block anti-apoptotic proteins. A recent clinical trial studied antisense deoxyoligonucleotides for $\mathrm{Bcl}-2 .{ }^{37}$ AML patients may, therefore, show a mechanism of protein stabilization and this has been observed in interactions with viral or other cellular proteins. ${ }^{38,39}$ Alternatively, in these patients our observations may represent a high level of constitutive expression, which has been reported previously. ${ }^{38}$

In summary, statistical analysis showed a significant correlation between p53 and $\mathrm{Bcl}-2$ protein. Therefore, these two apoptotic-regulating proteins may be considered prognostic marker for acute myeloid leukemia.

\section{References}

1. Vogelstein B. A deadly inheritance. Nature 1990;348:681-2.

2. Nigro JM, Baker SJ, Preisinger AC, et al. Mutation in the p53 gene occurs in diverse human tumor types. Nature 1989;342:705-8.

3. Hollstein M, Sidransky D, Vogelstein B, et al. p53 mutations in human cancers. Science 1991;253:49-53.

4. Greenblatt MS, Bennett WP, Hollstein M, et al. Mutations in the p53 tumour suppressor gene: Clues to cancer etiology and Molecular pathogenesis. Cancer Research 1994;54: 4855-78.

5. Imamura J, Miyoshi I, Koeffler HP. p53 in hematologic malignancies. Blood 1994;84: 2412-21.

6. Levine AJ, Momand J, Inlay CA. The p53 tumor suppressor gene. Nature 1991;351:4536.

7. Wattel E, Preudhomme C, Hecquet B, et al. p53 mutations are associated with resistance to chemotherapy and short survival in hematologic malignancies. Blood 1994;84:3148-57.

8. Hsiao $\mathrm{MH}, \mathrm{Yu} \mathrm{AL}$, Yeargin $\mathrm{J}$, et al. Nonhereditary p53 mutations in T-cell acute lymphoblastic leukemia are associated with the relapse phase. Blood 1994;83:2922-30.

9. Iccianni MB, Yu J, Hsiao M, et al: Clinical significance of p53 mutations in relapsed T-cell acute lymphoblastic leukemia. Br J Cancer 1999;79:1151.

10. Zhu YM, Foroni L, McQuaker IG, et al. Mechanisms of relapse in acute leukaemia, Involvement of p53 mutated subclones in disease progression in acute lymphoblastic leukemia. Br J Cancer 1999; 79:1151-7.

11. Tsujimoto Y, Cossman J, Jaffe E, et al. Involvement of the Bcl-2 gene in human follicular lymphoma. Science 1985;228: 1440-3.

12. Campos L, Rouault JP, Sabido 0, et al. High expression of Bcl-2 protein in acute myeloid leukemia cells is associated with poor response to chemotherapy. Blood 1993;81:3091-6.

13. Maung ZT, MaClean FR, Reid MM, et al. The relationship between Bcl-2 expression and response to chemotherapy in acute leukaemia. Br J Hematol 1994;88:105-9.

14. Campos L, Sabido 0, Sebba C, et al. Expression of Bcl-2 proto-oncogene in adult acute lymphoblastic leukemia. Leukemia 1996;10:434-8.

15. Lauria F, Raspador D, Rondelli D, et al. High Bcl-2 expression in acute myeloid leukemia cells correlates with CD34 positivity and complete remission rate. Leukemia 1997;11:20758.

16. Karakas T, Maurer U, Weidmann E, et al. High expression of Bcl-2 mRNA as a determinant of poor prognosis in acute myeloid leukemia. Annals Oncology 1998;9:159-65.

17. Hermine 0, Haioun $\mathrm{C}$, Lepage $\mathrm{E}$, et al. Prognostic significance of Bcl-2 protein expression in aggressive non-Hodgkin's lymphoma. Blood 1996;87:265-72.

18. Hill ME, MaCleannan KA, Caunnigham DC, et al. Prognostic significance of Bcl-2 expression and Bcl-2 major breakpoint region rearrangement in diffuse large cell non-Hodgkin's lymphoma, A British national lymphoma investigation study. Blood 1996;88:1046-51.

19. Moul JW, Mostofi FK, Bauer JJ. Protein expression of p53, Bcl-2 and KI-67 (MIB-1) as prognostic biomarkers in-patients with surgically treated, Clinically localized prostate cancer. Surgery 1996;120:159-66.

20. Bauer JJ, Sesterbenn IA, Mostofi FK, et al. Elevated levels of apoptosis regulator protein p53 and Bcl-2 are independent prognostic biomarkers in surgically treated clinically localized prostate cancer. J Urology 1996;156:15116.

21. Antonsson B, Conti F, Ciavatta A, et al. Inhibition of Bax channel forming activity by Bcl-2. Science 1997;277:370-2.

22. Pietenpol JA, Papadopoulos N, Markowitz S, et al. Paradoxical inhibition of solid tumour cell growth by Bcl-2. Cancer Research 1994;54:3714-7.

23. Borner C. Diminished cell proliferation associated with the death protective activity of Bcl2. J Biol Chem 1996;271:12695-8.

24. Gascoyne RD, Krajewska M, Krajewski S, et al. Prognostic significance of Bax protein Expression in Diffuse Aggressive NonHodgkins lymphoma. Blood 1997; 90:3173-8.

25. Koduru RKP, Karthik R, Vadmal V, et al. Correlation between mutation in p53, p53 expression, Cytogenetics, Histologic types and survival in patients with B-cell NonHodgkins lymphoma. Blood 1997;90:4078-91.

26. Kaplan EI and Meier P. Non-parametric estimation from incomplete observation. J Am Stat Assoc 1958;53:457-81.

27. Cox DR. Regression models and life-tables. J Royal Stat Society B 1972;34:187-220.

28. Steven MK, Peter FT, Zeev E, et al. The prognostic impact of BCL-2 protein expression in Acute Myelogenous Leukemia varies with Cytogenetics. Clinical Cancer Res 1999;5: 1758-66.

29. Prokocimer M and Rotter V: Structure and function fo p53 in normal cells and their aberrations in cancer cells, Projection on the haematologic cell lineages. Blood 1994;84: 2391-411.

30. Delia D, Aiello A, Soligo D, et al. Bcl-2 protooncogene expression in normal and neoplastic human myeloid cells. Blood 1992;79:12918.

31. Findley HW, Lubing GU, Yeager AM, et al. Expression and regulation of Bcl-2, Bcl-Xl, and Bax Correlate with p53 status and Sensitivity to Apoptosis in Childhood Acute Lymphoblastic Leukemia. Blood 1997;89: 2986-93.

32. Naumovski L, Martinovsky G, Wong $\mathrm{C}$, et al. Bcl-2 expresion does not correlate with patient outcome in pediatric acute mylegenous leukemia. Leuk Res 1989;22:81-7.

33. Banker DE, Groudine M, Norwood T, et al. Measurement of spontaneous and therapeutic agent-induced apoptosis with Bcl-2 protein expression in acute myeloid leukemia. Blood 1997;89:243-55.

34. Bensi L, Longo R, Vecchi A, et al. Bcl-2 oncoprotein expression in acute myeloid leukemia. Haematologica 1995;80:98-102.

35. Lepelley P, Soenen V, Preudhomme C, et al. Bcl-2 expression in myelodysplastic syndromes and its correlation with hematological features, p53 mutation and prognosis. Leukemia (Baltimore) 1995;9:726-30.

36. Yue B, Chen Y, Yu D, et al. Study on the relationship between the Bcl-2/Bax ratio and the growth types of leukemic cells and drug resistance in acute myelogenous leukemia. J Tongji Med Univ 1998;18:101-4.

37. Webb A, Cunningham D, Cotter F, et al. Bcl-2 antisense therapy in patients with nonHodgkin lymphoma. Lancet 1997;349:113741.

38. Vogelstein B and Kinzler KW. p53 function and dysfunction. Cell 1992;70:523-6.

39. Moll UM, Riou G, Levine AJ. Two distinct mechanisms alter p53 in breast cancer: Mutation and nuclear exclusion. Proc Natl Acad Sc USA 1992;89:7262-6. 